\title{
Technology Development of Rabbit Meat Semi-Finished Product of a High Degree of Readiness
}

\section{Roman A. VOROSHILIN}

Senior Lecturer

Department of Agrobiotechnology

Faculty of Agrobiotechnology

FSBEI HE Kuzbass State Agricultural Academy

5, Markovtseva Str., Kemerovo, Russia

\section{Marina G. KURBANOVA}

Ph.D. (in Technical Science)

Professor

Department of Agrobiotechnology

Faculty of Agrobiotechnology

FSBEI HE Kuzbass State Agricultural Academy

5, Markovtseva Str., Kemerovo, Russia

\section{Anastasia Y. KOLBINA}

Graduate Student

Department of Agrobiotechnology

Faculty of Agrobiotechnology

FSBEI HE Kuzbass State Agricultural Academy

5, Markovtseva Str., Kemerovo, Russia

\section{Abstract}

The chemical composition of rabbit meat makes it possible to use it in the production of semifinished meat products of a functional orientation, as it is recommended for children's, diet food, etc. The article proposes a scheme for the production carcasses' cutting of rabbits that received extracts of medicinal plants Echinacea Purpurea and Chamomile (Matricaria chamomilla) in the main diet to create an expanded assortment of convenience food and culinary products for retail chains and public catering systems. The formulation and technological scheme for the production of semi-finished products of a high degree of readiness from the meat of the longest muscle of the rabbit back carcasses was developed, and industrial testing was carried out. The product yield is calculated. The physicochemical and organoleptic characteristics of the semi-finished product, as 
IV International Scientific and Practical Conference "Modern S\&T Equipments and Problems in Agriculture"

well as indicators of nutritional and energy value, are estimated. According to the conducted microbiological studies, it is possible to recommend the shelf life of semi-finished products of a high degree of readiness from rabbit meat for 7 days at a temperature of $0-4{ }^{\circ} \mathrm{C}$.

Keywords: technological scheme; recipe; rabbit meat; semi-finished product of a high degree of readiness; product quality indicators.

\section{Introduction}

The market for meat products is growing every year, and accordingly, demand and competition for these types of products are growing as well (Cullere, 2018). In this regard, meat producers are considering options for more successful positioning of their products on the market, so for their products they begin to use animal breeding systems that provide high-quality and safe products that they can position as eco-friendly (Cullere, 2013).

One of the promising sectors of agriculture is rabbit breeding. Compared to other types of meat, rabbit meat has a high mass fraction of protein with a relatively low mass fraction of fat, contains significantly more vitamins B6, B12 and PP than beef, pork or lamb. Also, rabbit meat is characterized by a high content of minerals, including iron and calcium, necessary for the normal formation and development of the human body, as well as potassium. In addition, rabbit meat contains a small amount of sodium, which gives it dietary properties, and is relatively poor in cholesterol (Klyuchnikova, Slobodyanik, Sukhareva, Sokolov, 2012).

Rabbit meat is a common food product in many countries. In terms of nutrition, rabbit meat is ideal for all types of consumers (Safaei, Abhari, Khosroshahi, Hosseini, Jafari, 2019). This is especially useful in Western countries, whose diet is usually rich in fats and sodium, subjecting them to health problems such as obesity, cardiovascular disease and hypertension (Chwastowska-Siwiecka, 2013).

Currently, in retail chains, rabbit meat is mainly presented in the form of carcasses, which does not allow consumers to fully use raw materials for quick cooking of foods and dishes at home, as additional cutting and ultimately processing is necessary, which undoubtedly leads to loss of raw materials (Minashin, 2003). Due to the difficult anatomical structure of the carcass of a rabbit, special skills and abilities are required for cutting individual parts (Patieva, 2016).

Experience has shown that parts rich in bone tissue are preferably used for the preparation of first and second courses such as stews, as these fabrics give the product a pronounced aroma and taste, give transparent broths during cooking. Muscle tissue is the most valuable part of the carcass. Cuts and anatomical areas with a high proportion of muscle tissue are maximally used as independent products for the plastic functions of the body (Khramova, 2013). In this case, muscle tissue can be a 
part of products from whole cuts in combination with bone and adipose tissue, and can also be isolated from the cut and used independently (Ruleva, 2016).

\section{Methods}

Experimental research was carried out at the Department of Agrobiotechnology of the FSBEI HE "Kuzbass State Agricultural Academy". Physico-chemical studies were carried out in the research laboratory "Agroecology". Production testing was carried out in the Municipal Autonomous Institution "School Nutrition". To obtain reliable results of the experimental part of the work, we used modern equipment, generally accepted and standard research methods.

The mass fraction of moisture in the finished product was determined by drying the sample to constant weight according to GOST R 51479-99. The mass fraction of fat was determined by the Soxhlet method in accordance with GOST 23042-2015. The protein content was determined by conversion to total nitrogen protein as determined by the Kjeldahl method in accordance with GOST 25011-81. The moisture-retaining ability of meat was determined by methods developed by employees of All-Russian Scientific Research Institute of Meat Industry named after V.M. Gorbatov. The digestibility of the designed products was carried out in vitro. Organoleptic evaluation of rabbit meat was carried out in accordance with GOST 9959-91 according to the 9point system and according to GOST 7269-2015. Microbiological indicators of the finished product were determined according to GOST 9958.

The purpose of the research was to propose a scheme for the production cutting of carcasses of rabbits that received extracts of medicinal plants from Echinacea Purpurea and Chamomile (Matricaria chamomilla) in the main diet to create an expanded assortment of semi-finished products and culinary products for retail chains and public catering systems, as well as to present options for using various parts of carcasses of rabbits in the technology of baked products.

\section{Results}

During the study of the muscular system of rabbit carcasses to expand the assortment of semifinished products, it is advisable to form steaks by separating the longest back muscles.

Taking into account modern technological approaches, a scheme for industrial cutting of carcasses of rabbits is recommended (Figure 1). 


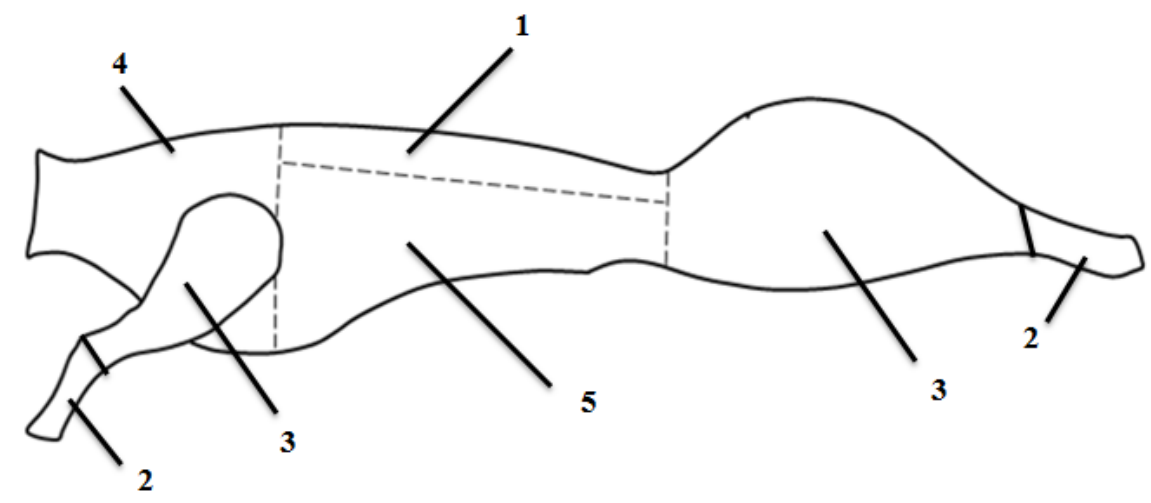

Figure 1. Scheme of industrial cutting of carcasses of rabbits: 1 - the longest back muscle (preparation of medallions); 2 - drumstick (cooking the first dishes); 3 - front and hind legs (cooking main dishes); 4 - cervicothoracic region (cutlet meat); 5 - frame (meat mechanically deboned)

After development of the proposed scheme for the industrial cutting of carcasses of rabbits, there were developed options for using various parts of rabbit carcasses in the technology for the production of meat products.

From the longest muscle of the back of rabbit carcasses (position 1 in Figure 1) in the conditions of the production hall of the Municipal Autonomous Institution "School Nutrition", a semi-finished product of a high degree of readiness was developed, technical documentation for a semi-finished product of a high degree of readiness was developed as well.

The formulation of the developed semi-finished product of high degree of readiness is presented in Table 1.

Table 1. Recipe of a semi-finished product of high degree of readiness from meat of the longest back muscle of rabbit carcasses

\begin{tabular}{lcc}
\multicolumn{1}{c}{ Name of raw materials } & Portion product, $\mathrm{g}$ & $\begin{array}{c}\text { Industrial processing, } \\
\mathrm{kg} / 100 \mathrm{~kg}\end{array}$ \\
\hline & Main raw materials & 68.6 \\
\hline $\begin{array}{l}\text { Meat of the longest back muscle of } \\
\text { rabbit carcasses }\end{array}$ & 150.0 & 18.0 \\
\hline Onion & 40.0 & 9.0 \\
\hline Mozzarella Cheese & 20.0 & 2.3 \\
\hline \multicolumn{2}{l}{ Spices and materials } & 1.0 \\
\hline Spices & 5.0 & 1.0 \\
\hline Salt & 2.0 & 100 \\
\hline Total & 2.0 & 85.6 \\
\hline Output & 219.0 & 1.0 \\
\hline
\end{tabular}


The technological scheme for the production of semi-finished products of high degree of readiness from meat of the longest back muscle of rabbit carcasses is shown in Figure 2.

The semi-finished product was heat treated in a cabinet oven of the three-section model ШЖЭ-3-К$2 / 1$ with gentle temperature conditions of $180-200{ }^{\circ} \mathrm{C}$ for $15-20$ minutes.

Then the semi-finished products of a high degree of readiness were cooled at a temperature of $0{ }^{\circ} \mathrm{C}$ to a temperature in the thickness of the product not higher than $4{ }^{\circ} \mathrm{C}$.

Cooled semi-finished products were packed in plastic containers, and then they were frozen at a temperature of $-18{ }^{\circ} \mathrm{C}$ to a temperature in the bulk of the product not higher than $-12{ }^{\circ} \mathrm{C}$. Before using, it is recommended to preheat semi-finished products for 5 to 20 minutes, depending on the design of the heat apparatus.

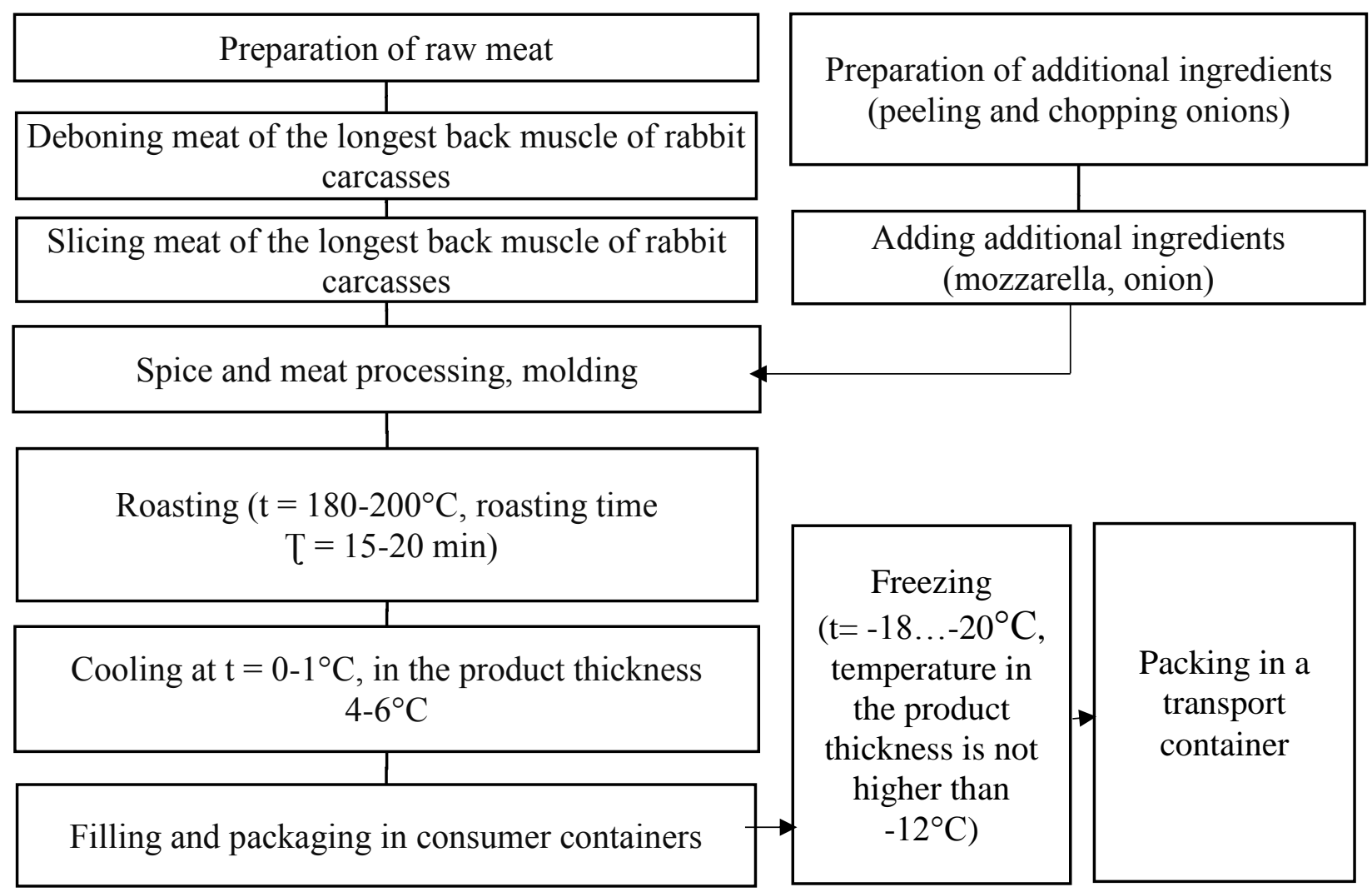

Figure 2. Technological scheme for the production of semi-finished products of a high degree of readiness from meat of the longest back muscle of rabbit carcasses

After cooling to a temperature in the thickness of the product $4-6{ }^{\circ} \mathrm{C}$, an assessment was made of the quantitative and qualitative indicators of the finished product from the meat of the longest back muscle of rabbit carcasses. 
Initially, the yield of the finished product, the $\mathrm{pH}$ level and the water-holding ability of semifinished products of a high degree of readiness were studied. Table 2 presents the results of studies of semi-finished products of high degree of readiness.

Table 2. Physico-chemical parameters of the semi-finished product of a high degree of readiness

\begin{tabular}{lc}
\multicolumn{1}{c}{ Parameter } & Content \\
\hline Mass fraction of moisture, $\%$ & $68.26 \pm 0.21$ \\
\hline Mass fraction of fat, \% & $4.17 \pm 0.12$ \\
\hline Mass fraction of protein, \% & $27.21 \pm 0.15$ \\
\hline Output of finished product, \% & $85.65 \pm 0.15$ \\
\hline pH & $6.25 \pm 0.09$ \\
\hline Water-holding capacity, $\%$ & $68.7 \pm 0.24$
\end{tabular}

According to the data of Table 2, it can be seen that the output of the product was $85 \%$, which indicates a high water-holding capacity, and this, again, is confirmed by the result of determining the water-holding capacity of the product. The results obtained indicate shallow denaturationcoagulation changes in protein macromolecules upon heating (Kozioł, 2015; Zelechowska, 2015).

The nutritional value of the semi-finished product of a high degree of readiness was evaluated by in vitro digestibility by the digestive enzymes pepsin and trypsin. Table 3 shows the average values of indicators.

Table 3. Digestibility of a semi-finished product of a high degree of preparedness from meat of the longest back muscle of rabbit carcasses

Enzymes $\quad$ mg of tyrosine / $g$ of protein

\begin{tabular}{lc}
\hline Trypsin & $7.35 \pm 0.11$ \\
\hline Pepsin & $9.18 \pm 0.21$ \\
\hline Amount of enzymes & $16.53 \pm 0.19$
\end{tabular}

As a result of studies, it was found that semi-finished products of a high degree of readiness from rabbit meat were equally susceptible to enzymes of the gastrointestinal tract, which suggests that connective tissue is equally affected by digestive enzymes.

Next, there was studied the nutritional and energy value of the obtained semi-finished products of high degree of readiness. Indicators of nutritional and energy values are presented in Table 4. 
Table 4. Indicators of nutritional and energy value of semi-finished products of a high degree of readiness from meat of the longest back muscle of rabbit carcasses

Indicators

\begin{tabular}{lc}
\hline Proteins, g/100g & $17.11 \pm 0.12$ \\
\hline Fats, g/100g & $9.54 \pm 0.215$ \\
\hline Carbohydrates, g/100g & $1.22 \pm 0.05$ \\
\hline Energy value, kcal/100g & $144.20 \pm 1.23$
\end{tabular}

The resulting semi-finished product of a high degree of readiness is characterized by a sufficiently high protein content in its composition, while it has a high energy value.

To determine the taste characteristics, odor, color and juiciness, an organoleptic evaluation of the finished semi-finished product was carried out according to a 9 point system. The evaluation results are presented in table 5 .

Table 5. Organoleptic characteristics of semi-finished meat from the longest back muscle of rabbit carcasses

\begin{tabular}{|c|c|c|c|c|c|c|}
\hline \multicolumn{6}{|c|}{ Indicators } & \multirow[t]{2}{*}{ Total score } \\
\hline $\begin{array}{c}\text { Appearanc } \\
\mathrm{e}\end{array}$ & Color & Odor, smell & Consistency & Taste & Juiciness & \\
\hline $8.8 \pm 0.3$ & $8.6 \pm 0.2$ & $8.5 \pm 0.2$ & $8.7 \pm 0.2$ & $8.6 \pm 0.3$ & $8.3 \pm 0.3$ & $8.6 \pm 0.3$ \\
\hline
\end{tabular}

\section{Discussion}

Based on the results of evaluating the organoleptic characteristics of a semi-finished product of a high degree of readiness from meat of the longest back muscle of rabbit carcasses, it can be concluded that the finished products are marked by high marks by the tasting committee. The total product score was 8.6 out of 9.0 points.

In order to establish the shelf life of the semi-finished product, we analyzed the microbiological contamination during storage at a temperature of 0 to $4{ }^{\circ} \mathrm{C}$.

According to the results of microbiological analysis of semi-finished products of a high degree of readiness from rabbit meat, it can be concluded that within 7 days the indicators of total bacterial contamination were within the acceptable standards of TS TC021/2011, while bacteria of the Escherichia coli group and sulfite-reducing clostridia were found during the entire storage period did not have (Nakyinsigeaf, 2018). Thus, the recommended shelf life of semi-finished products of a high degree of readiness from rabbit meat is 7 days at a temperature of $0-4{ }^{\circ} \mathrm{C}$. 


\section{Conclusion}

A scheme for the production carcasses cutting of rabbits, which received in the main diet extracts of medicinal plants Echinacea Purpurea (Echinacea purpurea) and Chamomile (Matricaria chamomilla), is proposed. The formulation and technological scheme for the production of semifinished products of a high degree of readiness from the meat of the longest beck muscle of rabbit carcasses was developed, and industrial testing was carried out. The product output was $85 \%$. Semifinished product of a high degree of readiness is characterized by a high content of proteins in its composition. Finished products were marked with a high score by the tasting committee, the total product score was 8.6 out of 9.0 points. Within 7 days, the indicators of total bacterial contamination were within the permissible norms of TR TS021/2011 requirements at a temperature of $0-4^{\circ} \mathrm{C}$.

\section{References}

Chwastowska-Siwiecka, I. (2013). Changes in the physicochemical properties of deep-frozen rabbit. Vet. Zootech-Lith, 62(84), 68-72.

Cullere, M. (2013). Effect of different rabbit prime cuts on raw and cooked proximate composition, cholesterol and fatty acids contents and nutrients true retention. 59th International Congress of Meat Science and Technology, 4, 18-23.

Cullere, M. (2018). Rabbit meat production and consumption: State of knowledge and future perspectives. Meat Science, 143, 137-146.

Khramova, V.N. (2013). Development of functional meat products using prebiotics and plant components of regional origin. Bulletin of the Lower Volga Agro-University Complex: Science and Higher Professional Education, 3(31).

Klyuchnikova, O.V., Slobodyanik, V.S., Sukhareva, I.A., Sokolov, A.V. (2012). Functional products based on rabbit meat. Successes in modern natural science, 6, 134-135.

Koziol, K. (2015). Changes in the color and $\mathrm{pH}$ of rabbit meat in the aging process. Med.Weter, 71(2), 104-108.

Minashin, Yu.F. (2003). Vitamins in rabbit meat. Rabbit breeding and fur farming, 6. Retrieved from: https://revolution.allbest.ru/agriculture/34550379_2.html

Nakyinsigeaf, K. (2018). Development of microbial spoilage and lipid and protein oxidation in rabbit meat. Meat Science, 143, 125-131. 
IV International Scientific and Practical Conference "Modern S\&T Equipments and Problems in Agriculture"

Patieva, S.V. (2016). The benefits and dietary characteristics of rabbit meat - a good offer for the modern consumer. Young scientists in solving actual problems of science, 154-158.

Ruleva, T.A. (2016). Rabbit meat as a dietary product. Its chemical composition and organoleptic characteristics. Innovative science, 3, 61-64.

Safaei, F., Abhari, K., Khosroshahi, N.K., Hosseini, H., Jafari, M. (2019). Optimisation of functional sausage formulation with konjac and inulin: using D-Optimal mixture design. Foods and Raw Materials, 7(1), 177-184.

Zelechowska, E. (2015). Effect of feeding season on pH, glycolytic potential, colour and myofibrillar proteins in rabbit meat. Article in Medycyna weterynaryjna, 71(12), 769-772. 